\title{
Induction of glycation suppresses glucokinase gene expression in HIT-T15 cells
}

\author{
Y.Kajimoto ${ }^{1}$, T. Matsuoka ${ }^{1}$, H. Kaneto ${ }^{1}$, H. Watada ${ }^{1}$, Y.Fujitani ${ }^{1}$, M.Kishimoto ${ }^{1}$, K. Sakamoto ${ }^{1}$, M. Matsuhisa ${ }^{1}$, \\ R. Kawamori ${ }^{2}$, Y. Yamasaki ${ }^{1}$, M. Hori ${ }^{1}$ \\ ${ }^{1}$ Department of Internal Medicine and Therapeutics, Osaka University Graduate School of Medicine, Suita, Osaka, Japan \\ ${ }^{2}$ Department of Medicine, Metabolism and Endocrinology, Juntendo University School of Medicine, Tokyo, Japan
}

\section{Abstract}

Aims/hypothesis. Chronic hyperglycaemia in patients with Type II (non-insulin-dependent) diabetes mellitus often leads to a decline in glucose-responsive insulin secretion from pancreatic beta cells, a phenomenon called glucose toxicity. Upon hyperglycaemia, glycation reaction occurs in the beta cells and induces oxidative stress. To understand the molecular basis of the beta-cell glucose toxicity, we investigated the possible effects of glycation on the expression and enzymatic activity of glucokinase, which plays a crucial part in glucose-responsive insulin secretion.

Methods. Glycation and reactive oxygen species were induced in HIT-T15 cells by treatment with D-ribose and effects on glucokinase gene transcription, glucokinase protein amount, glucose phosphorylation activity, and DNA-binding activities of putative glucokinase gene transcription factors were evaluated.

Results. When glycation was induced in HIT-T15 cells, the activity of the human glucokinase gene beta-cell-type promoter was suppressed substantially ( $83 \%$ reduction at $60 \mathrm{mmol} / \mathrm{l}$ D-ribose). Also, similar reductions in mRNA and protein amounts of glucokinase and in the Vmax of its enzymatic activity were observed. In agreement with the reduction in the promoter activity, the two major transcription factors of the glucokinase gene, the Pal-binding factor and PDX-1, reduced their binding to their target sequences in the glucokinase gene promoter in glycation-induced HIT cells. Because these effects of D-ribose were counteracted by aminoguanidine or $N$-acetylcysteine, reactive oxygen species, generated by the glycation reaction, appears to be involved in the phenomena.

Conclusion/interpretation. The induction of the glycation reaction, which is known to occur in pancreatic beta cells in chronic hyperglycaemia, suppresses the glucokinase gene transcription and its enzymatic activity. Thus, hyperglycaemia-dependent inhibition of glucokinase activity could in part explain beta-cell glucose toxicity. [Diabetologia (1999) 42: 1417-1424]

Keywords Gene expression regulation, transcription factors, glycosylation, homeodomain protein, oxidative stress.
Although glucose is the major physiologic stimulator of insulin secretion and biosynthesis in vivo, prolonged exposure of pancreatic beta cells to a high glu-

Received: 15 April 1999 and in revised form: 25 August 1999

Corresponding author: Dr. Y. Kajimoto, Department of Internal Medicine and Therapeutics (A8), Osaka University Graduate School of Medicine, 2-2 Yamadaoka, Suita City, Osaka Pref. 565-0871, Japan.

Abbreviations: GK, Glucokinase; ROS, reactive oxygen species; NAC, $N$-acetylcysteine; GLUT, glucose transporter. cose concentration in Type II (non-insulin-dependent) diabetes mellitus causes beta-cell dysfunction [1]. Despite the concept of glucose toxicity being well known, its biochemical background is poorly understood. Because beta cells abundantly express the high- $\mathrm{K}_{\mathrm{m}}$ glucose transporter (GLUT) 2 and thereby have highly efficient glucose uptake when exposed to a high glucose concentration, the glycation reaction and induction of reactive oxygen species, generated as a result of glycation, have been considered to also occur in beta cells. Recently, as support for this, an increase in advanced glycation end products was 
identified in pancreatic islet cells which had been kept in a high glucose concentration [2]. Also, the concentration of 8-hydroxy-2'-deoxyguanosine (8$\mathrm{OHdG}$ ), a marker for oxidative stress, is induced in beta cells of diabetic Goto-Kakizaki rats [3]. As support for the pathophysiological significance of these phenomena, we recently showed that the insulin gene promoter is sensitive to glycation or reactive oxygen species, generated as a result of glycation [4]. Also, as possible cause of the reduction of the promoter activity, suppression of the activity of the insulin gene transcription factor PDX-1 was observed in the cells treated with D-ribose [4].

In this study, we investigated the possible effects of glycation on the expression and activity of glucokinase (GK). Glucokinase, also known as type IV hexokinase, functions as the proximal and rate-limiting step in the utilization of glucose and thereby plays a crucial part in regulating insulin secretion by beta cells. Recently, it was shown that the insulin gene transcription factor PDX-1 is a potential regulator of $G K[5,6]$. Therefore, the suppression of PDX-1 activity, which occurs by induction of glycation, could affect the $G K$ gene expression. We show here that the induction of glycation in HIT-T15 cells suppresses the $G K$ gene promoter and decreases the GK mRNA amount and GK enzymatic activity. Thus, by inhibiting GK activity as well as insulin biosynthesis [4], the glycation reaction and oxidative stress, which seems to be induced in beta cells in diabetes $[2,3]$, is likely to play a critical part in beta-cell glucose toxicity.

\section{Materials and methods}

Cell culture and reporter gene analyses. Beta-cell-derived cell line HIT-T15 cells (ATCC no. 1777) were grown in RPMI1640 medium supplemented with $10 \%$ heat-inactivated fetal bovine serum, penicillin and streptomycin. The plasmids used in reporter gene analyses were pA3GKLuc/-280 [5], containing 280 base pairs of the $5^{\prime}$-flanking sequences and 41 base pairs of the exon $1 \beta$ untranslated region of the human betacell-type $G K$ gene. At 24 h before gene transfection, HIT-T15 cells were replated in six-well tissue culture plates. One microgram of the reporter gene plasmid pA3GKLuc/-280 was transfected into HIT-T15 cells by the lipofection method using lipofectamine reagent (Life Technologies, Tokyo, Japan) under the conditions recommended by the manufacturer. Then $6 \mathrm{~h}$ after the transfection $40 \mathrm{mmol} / \mathrm{l}$ or $60 \mathrm{mmol} / \mathrm{l} \mathrm{D}$-ribose or vehicle only $(0 \mathrm{mmol} / \mathrm{l})$ was added to the medium. When required, $1 \mathrm{mmol} / 1$ aminoguanidine or $10 \mathrm{mmol} / 1 \mathrm{~N}$-acetylcysteine (NAC) was also added simultaneously. After the additions, the cells were cultured for an additional $72 \mathrm{~h}$, after this cell lysates were harvested and then subjected to luciferase assays. Luciferase activities were normalized with respect to protein concentrations of the cell lysates.

Competitive RT-PCR. Total RNA was extracted from HIT-T15 cells kept for 5 days under 0,40 or $60 \mathrm{mmol} / \mathrm{l}$ D-ribose. Quantification of beta-actin and GK mRNA was done by RT-PCR us- ing the set of primers we described previously [7]. Extracted RNA (100 ng) was reverse-transcribed and amplified with a pre-estimated number of copies of the competitor DNA fragments, which were designed to be amplified by the same set of primers as were the original first strand cDNAs and were shorter than the cDNAs by 72 base pairs (for $G K$ ) or 81 base pairs (for beta-actin) [7]. All the PCR primers were designed to bypass at least one intron so that amplification of genomic DNA could be avoided. Two PCR products, one derived from the original cDNA and the other from the competitor, were separated on an agarose gel and the point of equivalence, i.e. where the ratio of the band intensity derived from cDNA to that of the competitor is closest to 1 , was determined. The experiment was repeated three times.

Western blotting. Cytoplasmic extracts were obtained from HIT-T15 cells kept for 5 days in 0 or $40 \mathrm{mmol} / \mathrm{l}$ D-ribose with or without $1 \mathrm{mmol} / \mathrm{l}$ aminoguanidine or $10 \mathrm{mmol} / \mathrm{l} \mathrm{NAC}$. From each extract $10 \mu \mathrm{g}$ were fractionated by SDS-PAGE (10\% resolving gel), and transferred to a nitrocellulose membrane (Nitrocellulose Blotting Membranes; Sartorius, Göettingen, Germany) using transfer buffer containing $20 \%$ methanol, $25 \mathrm{mmol} / \mathrm{l}$ TRIS base and $192 \mathrm{mmol} / \mathrm{l}$ glycine $(100 \mathrm{~V}, 1 \mathrm{~h})$. After blocking the membranes at $4^{\circ} \mathrm{C}$ overnight in blocking solution (Block Ace; Snow Brand Milk Products Co., Sapporo, Japan) with $2 \%$ BSA, the membranes were incubated at room temperature for $60 \mathrm{~min}$ in the same solution containing 1:500 diluted anti-GK polyclonal antibody (sc-7908; Santa Cruz Biotechnology, Santa Cruz, Calif., USA) or 1:100 diluted anti-actin IgM antibody (CP01; CN Biosciences, San Diego, Calif., USA), and washed four times (15 min each time) in TBS buffer $(20 \mathrm{mmol} / \mathrm{l}$ TRIS-HCl, $150 \mathrm{mmol} / \mathrm{l} \mathrm{NaCl}$, pH 7.5) with $0.2 \%$ Tween-20 (TBS-T). The membranes were then incubated for $60 \mathrm{~min}$ at room temperature in TBS buffer with $10 \%$ blocking solution, containing 1:2500 dilution of goat anti-rabbit IgG antibody (for GK detection) or 1:2000 dilution of goat anti-mouse IgM antibody (for actin detection) coupled to horseradish peroxidase, followed by four 15-min washings with TBS-T. Immunoreactive bands were made visible by incubation with luminol (ECL Western Blotting Kit; Amersham Japan) and exposed to an x-ray film (Fuji Photo Film Co., Tokyo, Japan). Quantification was achieved by densitometric scanning.

Evaluation of glucose phosphorylation activity. Glucose phosphorylation activity was measured by continuous assay. Cell lysates were prepared from HIT-T15 cells kept for 5 days in media containing 0,40 , or $60 \mathrm{mmol} / \mathrm{l} \mathrm{D}$-ribose with or without addition of $1 \mathrm{mmol} / \mathrm{l}$ aminoguanidine or $10 \mathrm{mmol} / \mathrm{l} \mathrm{NAC}$. The reaction solution $(1 \mathrm{ml})$ contained $100 \mu \mathrm{l}$ of the lysate, $50 \mathrm{mmol} / \mathrm{l}$ HEPES ( $\mathrm{pH} 7.4), 100 \mathrm{mmol} / \mathrm{l} \mathrm{KCl}, \quad 7.5 \mathrm{mmol} / \mathrm{l} \quad \mathrm{MgCl}_{2}$, $2.5 \mathrm{mmol} / 1$ dithiothreitol, $10 \mathrm{mg} / \mathrm{ml}$ albumin, $5 \mathrm{mmol} / \mathrm{l} \mathrm{ATP}$, $0.5 \mathrm{mmol} / 1 \mathrm{NAD}^{+}, 4$ units of glucose-6-phosphate dehydrogenase and $0.5,7,10,15,18$ or $50 \mathrm{mmol} / 1$ glucose. The reaction was allowed to continue for $20 \mathrm{~min}$ at $37^{\circ} \mathrm{C}$ and glucose phosphorylation was determined as the change in absorbance at $340 \mathrm{~nm}$ in the complete medium minus that in the absence of ATP. For statistical comparisons we used analysis of variance (ANOVA) followed by post hoc testing with the Fisher protected least significant difference test.

Preparation of nuclear extracts and gel mobility-shift analyses. Nuclear extracts were prepared from HIT-T15 cells and kept for 5 days in media containing 0,40 , or $60 \mathrm{mmol} / \mathrm{l} \mathrm{D}$-ribose with or without addition of $1 \mathrm{mmol} / \mathrm{l}$ aminoguanidine or $10 \mathrm{mmol} / \mathrm{l} \mathrm{NAC}$. From each nuclear extract $3 \mu \mathrm{g}$ were preincubated with $50 \mathrm{ng}$ of salmon sperm DNA (undenatured) at $4{ }^{\circ} \mathrm{C}$ 
in a 20 - $\mu$ l reaction mixture containing $20 \mathrm{mmol} / \mathrm{l}$ HEPES $\mathrm{pH}$ 7.9, $150 \mathrm{mmol} / \mathrm{l} \mathrm{NaCl}, 1 \mathrm{mmol} / \mathrm{l}$ EDTA and $3 \%$ Ficoll (w/v\%). After $15 \mathrm{~min}$, the binding reaction was initiated by adding 100 pg $\left(\sim 1 \times 10^{4} \mathrm{cpm}\right)$ of $5^{\prime} \mathrm{end}-\left[{ }^{32} \mathrm{P}\right]$ labelled oligonucleotide probes and, when required, non-radioactive competitor double-stranded oligonucleotides were added, followed by incubation at room temperature for $30 \mathrm{~min}$. Also, when required, $2 \mu \mathrm{l}$ of pre-immune serum or antiserum was added to the binding reaction mixtures. These samples were kept at room temperature for $30 \mathrm{~min}$ before addition of the binding probes. The anti-PDX-1 (IPF1) antibody was previously established by us [5] and anti-Oct-1 antibody was purchased from a commercial supplier (Santa Cruz Biotechnology). The samples were fractionated on $5 \%$ PAGE pre-cooled to $4{ }^{\circ} \mathrm{C}$ in $0.5 \times \mathrm{TBE}$ ( $45 \mathrm{mmol} / \mathrm{l}$ TRIS base, $45 \mathrm{mmol} / \mathrm{l}$ boric acid, $1 \mathrm{mmol} / \mathrm{l}$ EDTA).

\section{Results}

Effects of glycation on GK gene transcription. The $G K$ gene promoter activity was examined in HITT15 cells which had been treated with a sugar with strong reducing activity, D-ribose. We transfected a fusion gene plasmid, pA $3 G K L u c /-280$, into the HITT15 cells. The transfected cells were kept for $72 \mathrm{~h}$ with or without D-ribose and were then harvested for luciferase assays. The activity of the $G K$ gene promoter was suppressed down to $52 \pm 6 \%$ and $17 \pm 7 \%$ of the control $(0 \mathrm{mmol} / \mathrm{l} \mathrm{D}$-ribose $)$ when the cells were kept in the presence of $40 \mathrm{mmol} / \mathrm{l}$ and $60 \mathrm{mmol} / \mathrm{l}$ D-ribose, respectively (Fig. 1). These reductions in the $G K$ gene promoter were similar to those observed with the insulin gene promoter. Such decreases were not observed with the beta-actin gene promoter [4].

To investigate whether the reduction of the promoter activity by D-ribose was mediated through induction of glycation and reactive oxygen species (ROS), we examined the effects of coexistence of aminoguanidine or NAC, respectively. We found that the addition of $1 \mathrm{mmol} / \mathrm{l}$ aminoguanidine could lead to total $(52 \pm 6 \%$ to $124 \pm 19 \%$ for $40 \mathrm{mmol} / \mathrm{l} \mathrm{D}$-ribose) or semitotal $(17 \pm 7 \%$ to $87 \pm 11 \%$ for $60 \mathrm{mmol} / \mathrm{l}$ D-ribose) neutralization of the D-ribose effects on the $G K$ gene promoter activity (Fig. 1). Similarly, addition of $10 \mathrm{mmol} / \mathrm{l} \mathrm{NAC}$ totally blocked the D-ribose-responsive decrease of the $G K$ promoter activity $(52 \pm 6 \%$ to $118 \pm 17 \%$ for $40 \mathrm{mmol} / \mathrm{l} \mathrm{D}$-ribose; $17 \pm 7 \%$ to $110 \pm 22 \%$ for $60 \mathrm{mmol} / \mathrm{l}$ D-ribose; Fig.1). These results thus indicated that glycation and glycation-dependent ROS production suppress the $G K$ gene promoter.

We also investigated whether the suppression of the $G K$ gene promoter activity causes reduction of GK mRNA and protein. According to the result of competitive RT-PCR, GK mRNA amounts decreased when the HIT-T15 cells were kept for 5 days with 40 or $60 \mathrm{mmol} / \mathrm{l}$ D-ribose $(5.2 \times 10$ copies / ng total RNA $(0 \mathrm{mmol} / \mathrm{l} \mathrm{D}$-ribose $)$ to $2.6 \times 10(40 \mathrm{mmol} / \mathrm{l}$ D-ribose $)$ or $1.3 \times 10(60 \mathrm{mmol} / \mathrm{l}$ D-ribose $)$ copies $/ \mathrm{ng}$
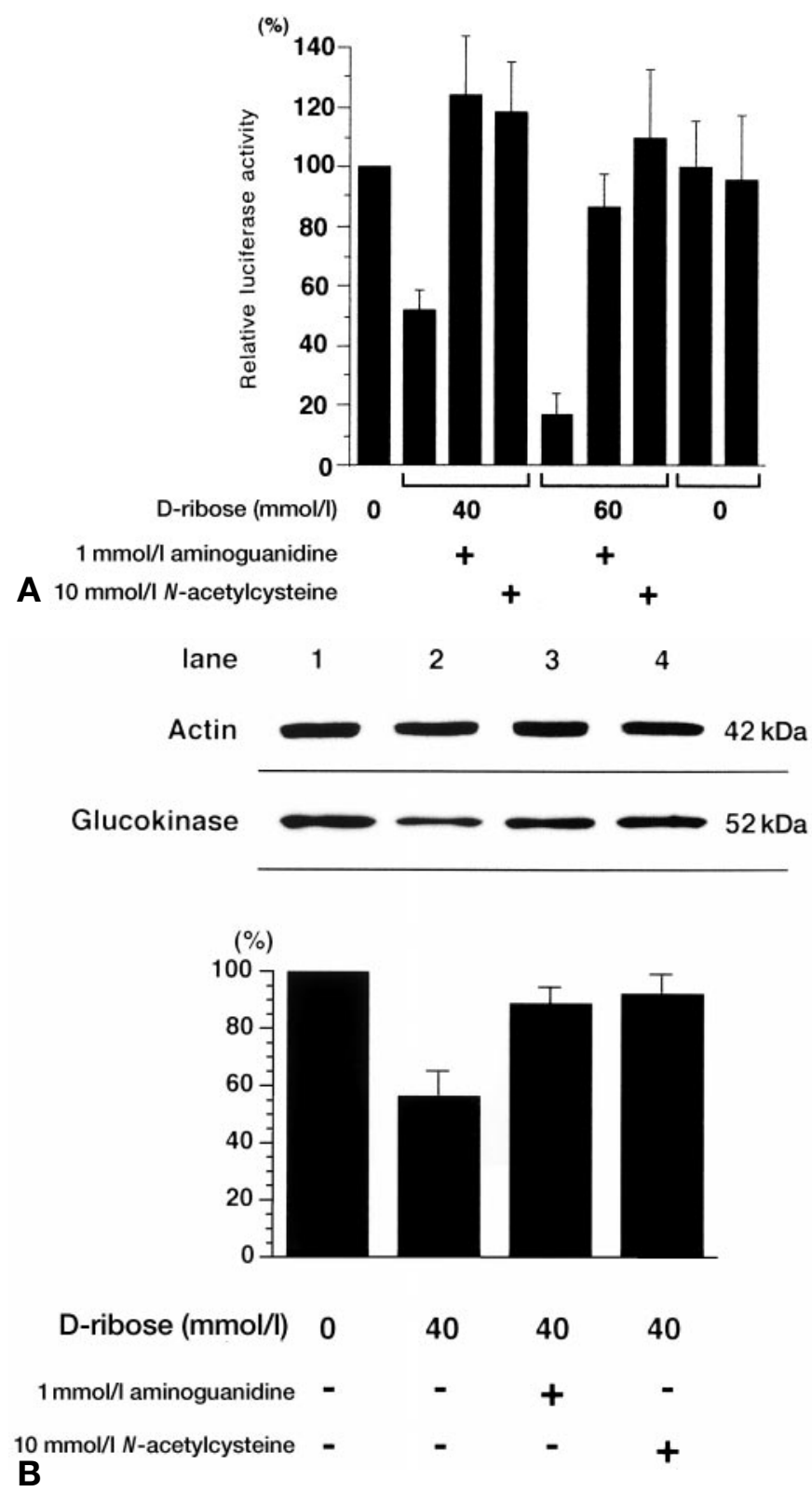

Fig. 1. A Evaluation of $G K$ gene transcription. The effect of glycation on the $G K$ gene promoter activity was evaluated in HIT cells by reporter gene analyses. As indicated, the cells were cultured in $0 \mathrm{mmol} / \mathrm{l}, 40 \mathrm{mmol} / \mathrm{l}$ or $60 \mathrm{mmol} / \mathrm{l} \mathrm{D}$-ribose with or without $1 \mathrm{mmol} / \mathrm{l}$ aminoguanidine or $10 \mathrm{~mol} / \mathrm{l} \mathrm{NAC}$. The results are presented as relative luciferase activity with that in D-ribose-untreated $(0 \mathrm{mmol} / \mathrm{l})$ HIT cells arbitrarily set at $100 \%$. All data are presented as means \pm SD of at least four individual experiments. B Evaluation of GK protein amount. The effect of glycation was evaluated by Western blot analyses. Cytoplasmic extracts were obtained from HITT15 cells kept for 5 days in $0 \mathrm{mmol} / \mathrm{l}$ (control; lane 1 ) or $40 \mathrm{mmol} / \mathrm{l}$ D-ribose without (lane 2 ) or with $1 \mathrm{mmol} / \mathrm{l}$ aminoguanidine (lane 3) or $10 \mathrm{mmol} / \mathrm{l} \mathrm{NAC} \mathrm{(lane} \mathrm{4).} \mathrm{The} \mathrm{antibodies}$ used were anti-GK antibody (middle) and anti-actin antibody (upper). The band intensity for GK was measured using laser scanning densitometry and expressed in bar graphs (below) as means \pm SD $(n=4)$ with the control lane (lane 1$)$ arbitrarily set at $100 \%$ 


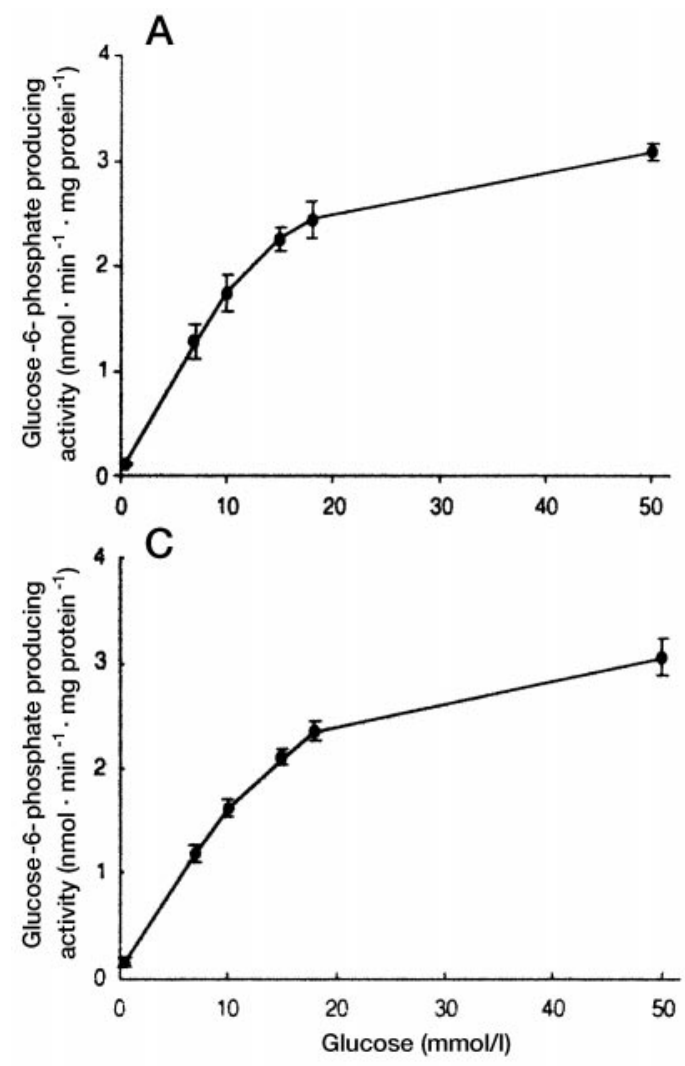

Fig.2A-D. Evaluation of glucose phosphorylation activity. Glucose phosphorylation activity was evaluated in HIT-T15 cells kept for 5 days in $0 \mathrm{mmol} / \mathrm{l}$ (vehicle only, A), $40 \mathrm{mmol} / \mathrm{l}$ D-ribose (B), $40 \mathrm{mmol} / \mathrm{l}$ D-ribose with $1 \mathrm{mmol} / \mathrm{l}$ aminoguani-

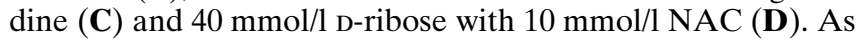
substrates of hexokinases, $0.5,7,10,15,18$ or $50 \mathrm{mmol} / \mathrm{l} \mathrm{glu-}$ cose was used. All data are presented as means \pm SD of at least four independent experiments. $\mathrm{V}_{\max }: 3.90 \pm 0.14 \quad$ (A), $2.35 \pm 0.57$ which is a significant difference from the other values $(p<0.01)(\mathbf{B}), 3.94 \pm 0.22 \quad(\mathbf{C}), 3.95 \pm 0.26 \quad(\mathbf{D}) . \quad \mathrm{K}_{\mathrm{m}}$ :

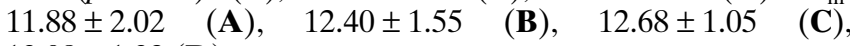
$13.08 \pm 1.32(\mathbf{D})$

total RNA; data not shown). The amounts of beta-actin mRNA in those HIT-T15 cells were not affected by the presence of $40 \mathrm{mmol} / \mathrm{l}$ or $60 \mathrm{mmol} / \mathrm{l} \mathrm{D}$-ribose for 5 days $\left(2.1 \times 10^{3}\right.$ copies per ng total RNA; data not shown). Similarly, the amounts of GK protein as assessed by western blot analyses decreased in HITT15 cells which had been kept for 5 days with $40 \mathrm{mmol} / 1$ D-ribose (Fig. 1). This effect of D-ribose was also well neutralized by the addition of $1 \mathrm{mmol} / \mathrm{l}$ aminoguanidine or $10 \mathrm{mmol} / \mathrm{l} \mathrm{NAC} \mathrm{(Fig.1).}$

Glycation-dependent reduction of glucose phosphorylation activity. To evaluate whether the reduction of $G K$ gene transcription due to glycation leads to decreased enzymatic activity of GK, glucose phosphorylation activity in the HIT-T15 cells was examined. As described previously [8], high- $\mathrm{K}_{\mathrm{m}}$ glucose phos-

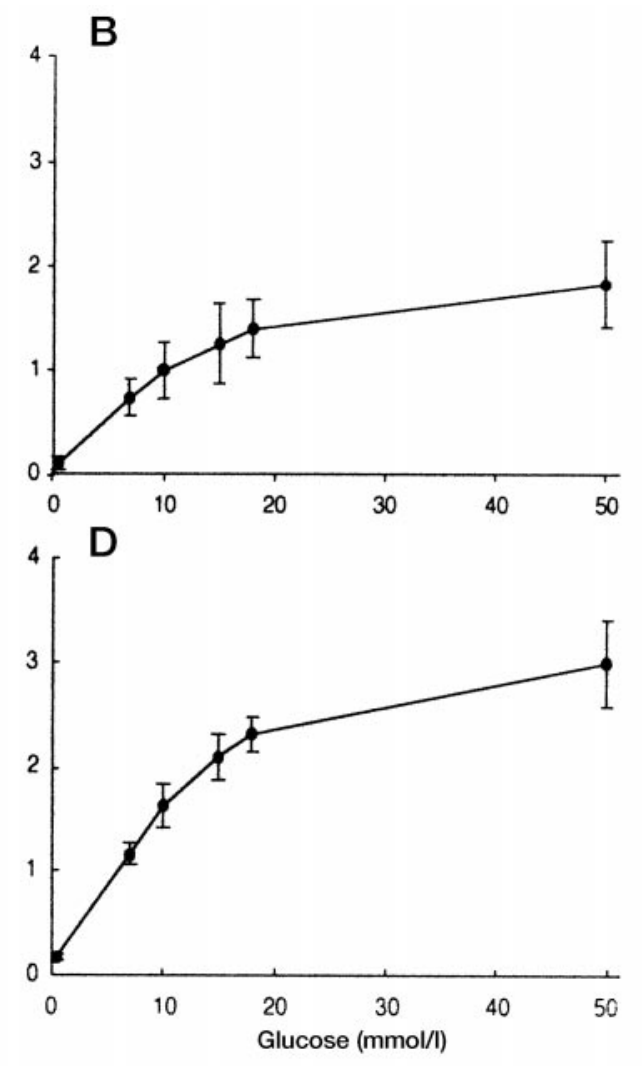

phorylation activity was detectable in the HIT-T15 cells (Fig.2), suggesting that the activity is primarily derived from GK rather than from other isozymes of hexokinase. When the HIT-T15 cells were kept with $40 \mathrm{mmol} / \mathrm{l}$ D-ribose, the $\mathrm{V}_{\max }$ was reduced (3.90 \pm 0.14 to $2.35 \pm 0.57 ; p<0.01$ ) without significant changes in the $K_{m}$ values $(11.88 \pm 2.02$ to $12.40 \pm 1.55$; Fig. 2). The reduction in $\mathrm{V}_{\max }$ was also prevented by aminoguanidine or NAC (Fig. 2). Because the degree of reduction in enzyme activity $\left(\mathrm{V}_{\max }\right)$ of GK $(40 \%)$ was similar to that in its gene transcription ( $48 \%$; Fig. 1$)$ or in its protein amount (43\%; Fig. 1), we suggest that the glycation-dependent suppression of the promoter activity is primarily responsible for the suppression of the enzyme activity.

Glycation-dependent reduction in PDX-1 activity and Pal-1-binding activity. The expression of the human $G K$ gene in beta cells was recently shown to depend on the two major cis-acting elements: the PDX-1binding UPE3 site $[5,9]$ and the Pal site $[9,10]$. First we examined whether this observation is conserved with its binding to the UPE3 site of the human $G K$ gene (hUPE3; [5]). Nuclear proteins were obtained from D-ribose-treated or untreated cells and gel-mobility shift assays were done. As observed previously [5], the gel-shift complex formed with the hUPE3 site could be recognized by the anti-PDX-1 antiserum (Fig. 3). When the cells were kept with 40 or $60 \mathrm{mmol} / 1$ D-ribose, the band intensity was substantially de- 


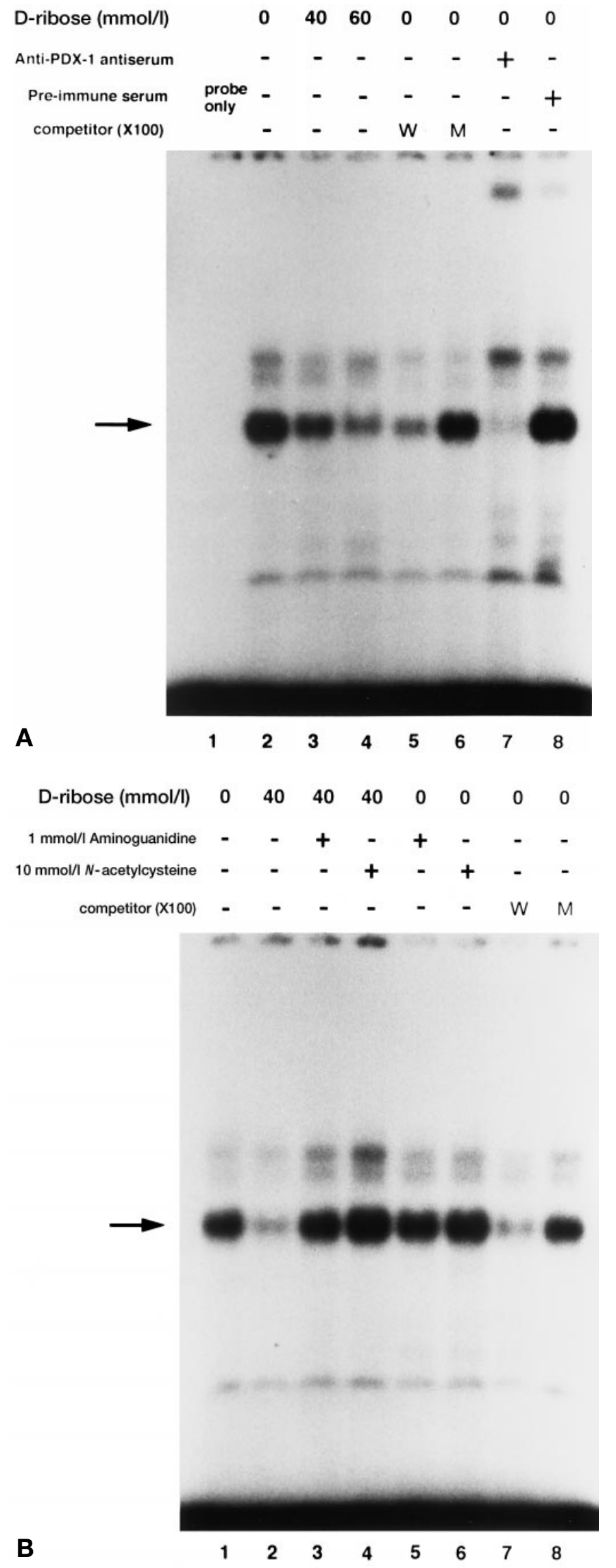

Fig. 3 A, B. Evaluation of hUPE3 site-binding activity. The effect of D-ribose on the hUPE3 site-binding activity was evaluated. Nuclear extracts were prepared from HIT-T15 cells kept in $0 \mathrm{mmol} / \mathrm{l} 40 \mathrm{mmol} / \mathrm{l}$, or $60 \mathrm{mmol} / \mathrm{l}$ D-ribose $(\mathbf{A})$ or in $40 \mathrm{mmol} / \mathrm{l}$ D-ribose without or with the co-existence of $1 \mathrm{mmol} / \mathrm{l}$ aminoguanidine or $10 \mathrm{mmol} / 1 \mathrm{NAC}(\mathbf{B})$. A doublestranded oligonucleotide reproducing the human $G K$ gene hUPE3 (5'-GGCAGCTCTAATGACAGGAT-3'; [5] was used as a binding probe. Where indicated, 100-fold excess of unlabelled wild-type (W) or mutated-type (M; 5'GGCAGCTCTCCTGACAGGAT-3') competitor or antiPDX-1 antiserum or pre-immune serum was added. An arrow indicates a band for the specifically formed gel-shift complex

creased. Also, the suppression by $40 \mathrm{mmol} / \mathrm{l} \mathrm{D}$-ribose was not observed in the presence of $1 \mathrm{mmol} / \mathrm{l}$ aminoguanidine or $10 \mathrm{mmol} / \mathrm{l} \mathrm{NAC} \mathrm{(Fig.} \mathrm{3).}$

Further to understand the molecular basis of the suppression of $G K$ gene promoter activity, we investigated the effects of D-ribose on the activity of Palbinding protein $[5,9,10]$. Using the human Pal-1 site (hPal-1; [5]) as a binding probe, gel-mobility shift analyses were done. All the specific bindings to the Pal-1 site (arrows; Fig. 4A) were suppressed by the presence of $40 \mathrm{mmol} / \mathrm{l}$ or $60 \mathrm{mmol} / \mathrm{l} \mathrm{D}$-ribose and the suppression was neutralized by the addition of $1 \mathrm{mmol} / \mathrm{l}$ aminoguanidine or $10 \mathrm{mmol} / \mathrm{l}$ NAC (Fig.4B). In contrast to the phenomena observed with PDX-1 and the Pal-binding factor, the activity of the octamer motif-binding nuclear protein Oct-1, which is known to be expressed ubiquitously, was not influenced at all by addition of D-ribose (Fig. 5). Thus, the two major transcription factors of the human $G K$ gene were glycation-sensitive and ROS-sensitive.

\section{Discussion}

Heterozygous mutations in the $G K$ gene were identified in patients with maturity-onset diabetes of the young (MODY) and in ordinary Type II diabetic patients $[11,12]$. Defects in the $G K$ gene seemed to be involved in the pathogenesis of diabetes, mainly due to blunting of glucose-responsive insulin secretion [13]. Because those patients are usually heterozygotes, not homozygotes, of $G K$ gene mutations, we consider that relative insufficiency of $G K$ gene expression could be implicated, at least in part, in the pathophysiology of Type II diabetes in some patients.

In our study, we found that the glycation reaction, when induced by D-ribose in HIT-T15 cells derived from beta cells, suppresses the promoter activity of the $G K$ gene and decreases the GK mRNA amounts and enzymatic activity (Fig.1). Glycation and oxidative stress is induced by D-ribose in a way which is similar to that for glucose and its metabolites such as 


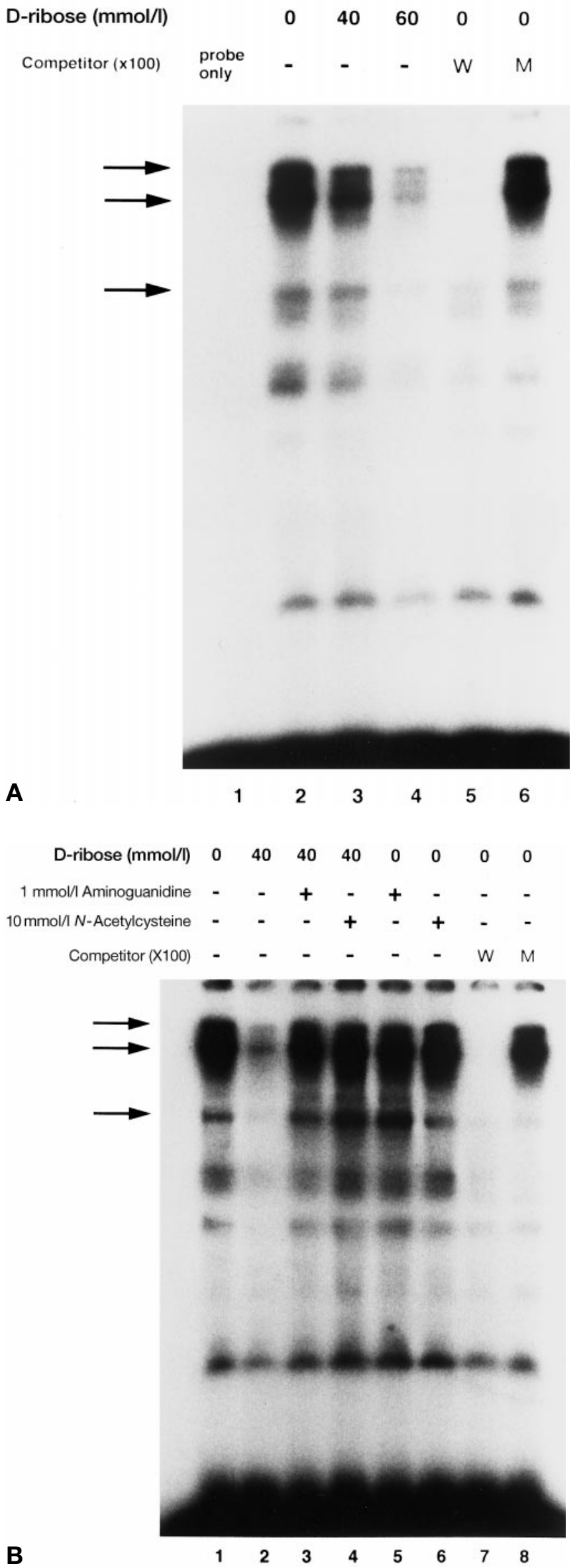

Fig. 4 A, B. Evaluation of hPal-1 site-binding activity. The effect of D-ribose on the hPal-1 site-binding activity was evaluated. Nuclear extracts were prepared from HIT-T15 cells kept in $0 \mathrm{mmol} / \mathrm{l}, 40 \mathrm{mmol} / \mathrm{l}$, or $60 \mathrm{mmol} / \mathrm{l} \mathrm{D}$-ribose without $(\mathbf{A})$ or in $40 \mathrm{mmol} / \mathrm{l}$ D-ribose without or with the co-existence of $1 \mathrm{mmol} / \mathrm{l}$ aminoguanidine or $10 \mathrm{mmol} / 1 \mathrm{NAC}(\mathbf{B})$. A doublestranded oligonucleotide reproducing the human $G K$ gene hPal-1 region (5'-ATTGAGTGGTCACCATGGTG-3'; [5] was used as the binding probe. Where indicated, 100 -fold excess of unlabelled wild-type (W) or mutated-type competitor (M; 5'-ATTGAGTGGTCCTACATGGTG-3') competitor was added. Arrows indicate bands for the specifically formed gel-shift complexes, among which the lowest band in each panel seems to correspond to the neuroendocrine cell-specific complex (complex c; [10]) reported previously

glucose-6-phosphate and fructose. Unlike glucose Dribose can, however, quickly induce oxidative stress due to its strong potency as a reducing sugar, which allows experiments such as reporter gene analyses. Although the strong reducing activity of D-ribose could cause reduction in cell viability, the suppressive effect on the promoter activity was observed for the $G K$ gene (Fig. 1) and insulin gene but not for the beta-actin gene [4]. Also, the activity of the two tissue-specific transcription factors, PDX-1 and Pal-1, were suppressed, but that of Oct-1 was not influenced at all (Fig. 5). We therefore assume that the phenomenon we observed is attributable to impairment of specific transcription factors rather than to more generalized events such as a decrease in general cell viability. Because the reduction in the enzymatic activity $\left(\mathrm{V}_{\text {max }}\right.$; Fig. 2) was similar to that in the relative luciferase activity (Fig.1A) and in the protein amount (Fig.1B), the suppressive effects of D-ribose seemed to be exerted at the level of transcription rather than post-translationally. Absence of change in the $\mathrm{K}_{\mathrm{m}}$ value supports this idea (Fig.2). As glycation reaction and induction of oxidative stress seem to occur in beta cells in diabetes [2, 3], a similar phenomenon could also be responsible, at least in part, for the impairment of glucose-responsive insulin secretion in diabetes. The observation of a decrease in the GK mRNA amounts in pancreatic islets of Zucker diabetic fatty rats as they become diabetic support this [14].

As a possible cause of the reduction in the $G K$ gene promoter activity, we identified a reduction in DNA-binding activities of PDX-1 (Fig. 3) and the Pal-site-binding factor (Fig. 4). Although the activity of Oct-1 was not affected by the addition of D-ribose (Fig.5), the fragility of those transcription factors could explain the characteristic fragility of the $G K$ gene promoter to glycation or ROS. Among the two transcription factors, PDX-1 is also implicated in insulin gene expression and has been suggested as being involved in the reduction of its transcription 

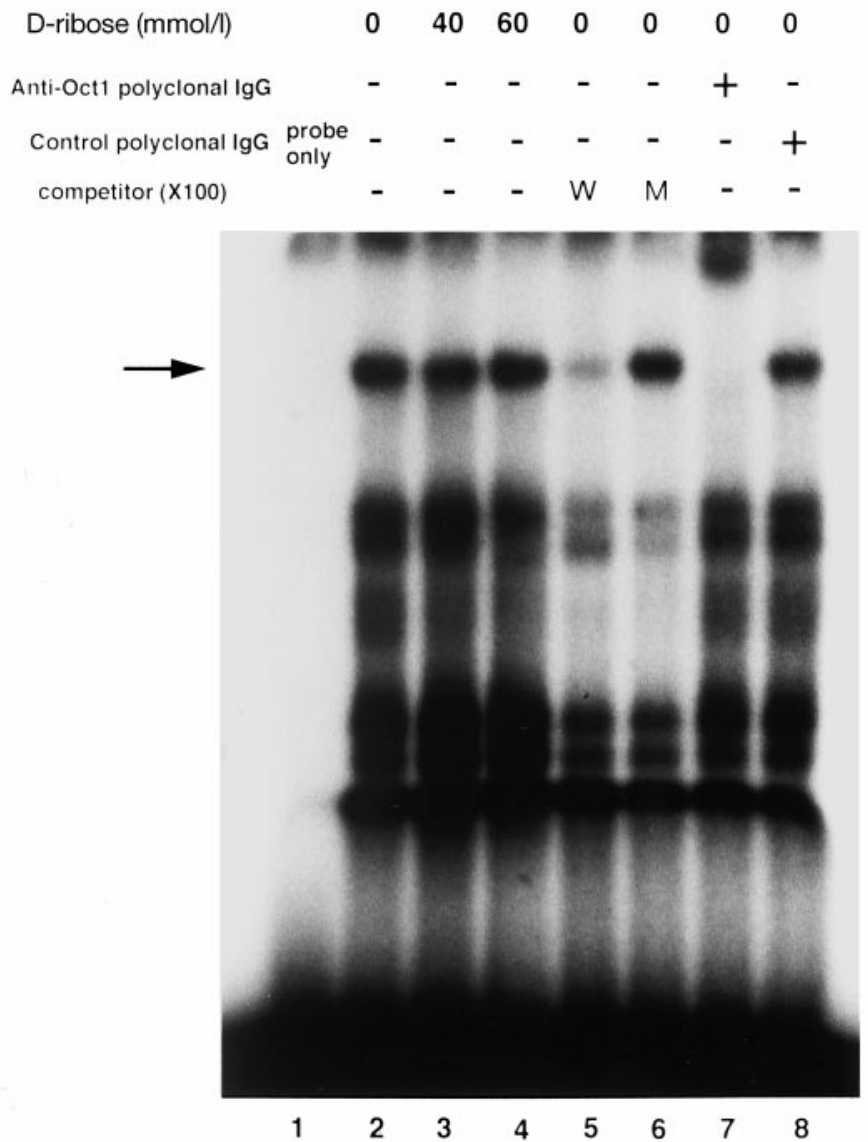

Fig. 5. Evaluation of DNA-binding activity for Oct-1. The effect of D-ribose on the DNA-binding activity for Oct- 1 was evaluated. Nuclear extracts were prepared from HIT-T15 cells $\mathrm{kept}$ in $0 \mathrm{mmol} / \mathrm{l}, 40 \mathrm{mmol} / \mathrm{l}$, or $60 \mathrm{mmol} / \mathrm{l} \mathrm{D}$-ribose. A doublestranded oligonucleotide probe reproducing the consensus octamer motif (5'-TGTCGAATGCAAATCACTAGAA- 3 ')was used as a binding probe. Where indicated, 100-fold excess of unlabelled wild-type $(\mathrm{W})$ or mutated-type (M; 5'TGTCGAATGCAAGCCACTAGAA-3') competitor or anti-Oct-1 polyclonal IgG or control IgG was added. An arrow indicates a band for the specifically formed gel-shift complex

upon glucose toxicity [15]. Even though the Pal-sitebinding factor is yet to be cloned the physiological involvement of the factor in $G K$ gene expression has been suggested $[9,10]$. Unlike insulin gene expression which is entirely restricted to beta cells, the beta-cell-type (upstream) $G K$ gene promoter is active in multiple neural/neuroendocrine cells of the pancreas, brain and gut. It has recently been shown that one of the Pal-binding factors (complex c; [10]) can be identified in GK-expressing neuroendocrine cells but not in non-neuroendocrine cells. As disruption of the Pal-1-motif in mouse and human $G K$ genes causes a decrease in the promoter activity which is even greater than that observed with the disruption of the PDX-1-binding UPE3 (hUPE3) element $[5,9]$, it is likely that the inhibition of the Palbinding factor observed in the glycation-induced HIT cells has pathophysiological significance.
In conclusion, the induction of glycation in beta cells suppresses the $G K$ gene transcription and its enzymatic activity. As the phenotype of the heterozygotes of the $G K$ gene mutation in humans supports the pathophysiological significance of the amount of $G K$ gene expression [11-13], the glycation and ROSdependent inhibition of $G K$ activity could explain in part the beta-cell glucose toxicity.

Acknowledgements. We thank Dr. Y. Tanizawa of Yamaguchi University School of Medicine for kindly providing the plasmid containing the human $G K$ gene promoter region, Dr. W. M. Wood of University of Colorado Health Science Center and Dr. D. R. Helinski of University of California San Diego for the luciferase plasmids. We also thank Ms. N. Fujita for excellent technical assistance. This study was supported in part by grants from Suzuken Memorial Foundation (to Y. Kajimoto) and Grant-in-Aid for Scientific Research from the Ministry of Education of Japan (to Y. Kajimoto and Y. Yamasaki).

\section{References}

1. Yki-Järvinen H (1992) Glucose Toxicity. Endocr Rev 13: 415-431

2. Tajiri Y, Möller C, Grill V (1997) Long-term effects of aminoguanidine on insulin release and biosynthesis: evidence that the formation of advanced glycosylation end products inhibits beta cell function. Endocrinology 138: 273-280

3. Ihara Y, Toyokuni S, Uchida K et al. (1999) Hyperglycemia causes oxidative stress in pancreatic beta-cells of GK rats, a model of type 2 diabetes. Diabetes 48: 927-932

4. Matsuoka T, Kajimoto Y, Watada H et al. (1997) Glycation-dependent, reactive oxygen species-mediated suppression of the insulin gene promoter activity in HIT cells. J Clin Invest 99: 144-150

5. Watada H, Kajimoto Y, Umayahara Yet al. (1996) The human glucokinase gene beta-cell-type promoter: an essential role of insulin promoter factor 1 (IPF1)/PDX-1 in its activation in HIT-T15 cells. Diabetes 45: 1478-1488

6. Watada H, Kajimoto Y, Miyagawa J et al. (1996) PDX-1 induces insulin and glucokinase gene expression in aTC1 clone6 cells in the presence of betacellulin. Diabetes 45: 1826-1831

7. Matsuoka T, Kajimoto Y, Watada H et al. (1995) Expression of CD38 gene, but not of mitochondrial glycerol-3phosphate dehydrogenase gene, is impaired in pancreatic islets of GK rats. Biochem Biophys Res Commun 214: 239-246

8. Shimizu T, Knowles BB, Matschinsky FM (1988) Control of glucose phosphorylation and glucose usage in clonal insulinoma cells. Diabetes 37: 563-568

9. Shelton KD, Franklin AJ, Khoor A, Beechem J, Magnuson MA (1992) Multiple elements in the upstream glucokinase promoter contribute to transcription in insulinoma cells. Mol Cell Biol 12: 4578-4589

10. Moates JM, Shelton KD, Magnuson MA (1996) Characterization of the Pal motifs in the upstream glucokinase promoter: binding of a cell type-specific protein complex correlates with transcriptional activation. Mol Endocrinol 10: 723-731

11. Vionnet N, Stoffel M, Takeda J et al. (1992) Nonsense mutation in the glucokinase gene causes early-onset non-insulin-dependent diabetes mellitus. Nature 356: 721-722 
12. Froguel P, Zouali H, Vionnet N et al. (1993) Familial hyperglycemia due to mutations in glucokinase. Definition of a subtype of diabetes mellitus. $\mathrm{N}$ Engl J Med 328: 697-702

13. Velho G, Froguel P, Clement K et al. (1992) Primary pancreatic beta-cell secretory defect caused by mutations in glucokinase gene in kindreds of maturity onset diabetes of the young. Lancet 340: 1162-1163
14. Tokuyama Y, Sturis J, DePaoli AM et al. (1995) Evolution of beta-cell dysfunction in the male Zucker diabetic fatty rat. Diabetes. 44: 1447-1457

15. Robertson RP, Olson LK, Zhang HJ (1994) Differentiating glucose toxicity from glucose desensitization: a new message from the insulin gene. Diabetes 43: 1085-1089 